\title{
TTR
}

Traduction, terminologie, re?daction

\section{Ruth A. Roland. Interpreters as Diplomats: A Diplomatic History of the Role of Interpreters in World Politics, Ottawa, University of Ottawa Press, 1999, 209 p.}

\section{Ian Martin}

Volume 15, numéro 1, 1er semestre 2002

La traduction au Canada : Tendances et traditions

Translation in Canada : Trends and Traditions

URI : https://id.erudit.org/iderudit/006810ar

DOI : https://doi.org/10.7202/006810ar

Aller au sommaire du numéro

Éditeur(s)

Association canadienne de traductologie

ISSN

0835-8443 (imprimé)

1708-2188 (numérique)

Découvrir la revue

Citer ce compte rendu

Martin, I. (2002). Compte rendu de [Ruth A. Roland. Interpreters as Diplomats: A Diplomatic History of the Role of Interpreters in World Politics, Ottawa,

University of Ottawa Press, 1999, 209 p.] TTR, 15(1), 244-247.

https://doi.org/10.7202/006810ar d'utilisation que vous pouvez consulter en ligne.

https://apropos.erudit.org/fr/usagers/politique-dutilisation/ 
The difficulty with describing this paper as a publication stems from the author's and the reader's differing expectations. Trosberg is not suggesting an original contribution to discourse studies itself. Hers is a pedagogic approach, not a model, and it is eclectic. As Christina Schäffner points out in what is labelled an editorial rather than an introduction, the use of some terms from the Halliday school of linguistics and some from discourse linguistic perspectives leads to terminological confusion, a confusion compounded by personal uses of terms well defined as having different meanings elsewhere (Peter Newmark's remarks p. 57). In addition, the long list of factors Trosberg suggests be considered leads to the question of what has been left out. Beverly Adab raises this issue (p. 71) in her response to Trosberg.

To sum up, then, the interest of this volume is the debate about the amount and kind of overt analysis that will prove useful in the translation classroom.

\section{Candace Séguinot \\ School of Translation, Glendon College York University}

\section{Ruth A. Roland. Interpreters as Diplomats: A Diplomatic History of the Role of Interpreters in World Politics, Ottawa, University of Ottawa Press, 1999, 209 p.}

This is a reprint in the University of Ottawa's series Perspectives on Translation (ed. Jean Delisle) of a 1982 book (Translating World Affairs) written by Roland, a retired Georgia State University political scientist and historian of diplomacy. The University of Ottawa has done the academic community of translators and interpreters a great service, because this is an immensely informative and enjoyable book, and one which, although dealing with much more than interpreting, will inspire budding interpreters and trainers of interpreters for years to come.

Roland surveys nothing less than the history of diplomatic interpreting from its origins in recorded history (c. 2600 B.C. in Mesopotamia and 165 B.C. in China) up to 1980, devoting a chapter to each of:

1. the Ancient Near East, Classical Greece and Rome, and Europe to the Renaissance 
2. Post-Renaissance Europe, the decline of Latin and the rise of national languages as languages of inter-state communication (to 1919); Europe-Turkey communication, and language questions in European contact with native peoples of the New World.

3. diplomatic relations between the West and China, Japan and India in the nineteenth century

4. diplomatic interpreting from Versailles to the United Nations

5. outstanding interpreters of the 20th century

Roland's method is to sketch a series of broad historical backgrounds within which she recounts specific anecdotes of inter-state diplomacy which illustrates various aspects of interpreters' skill. But a common thread running throughout the book is Roland's great respect and admiration for her gallery of outstanding interpreters. In particular, she is interested in "political linguists" (she uses the term linguist in the earlier sense of one proficient in languages), and in analysing the origins of their skill, as well as characterizing them as cultivated intercultural men (almost all of her examples are of male interpreters a noticeable exception is Malintzin/Malinche, the famous/notorious Mexican interpreter/mistress of Cortes, fluent in Spanish, Mayan and Aztec).

One cannot read this book without being convinced of the critical, but often unacknowledged, importance of interpreters throughout the history of interstate relations. Without exception, Roland presents them as "more than interpreter": in many ways they were diplomats in their own right. Prior to the late nineteenth century, the distinction made today between interpreters and translators was not sharply drawn. The examples Roland cites were both literate and gifted speakers, true internationalists, often working in the course of their lives for a number of states. (Sometimes, as in the famous case of Friedrich von Gentz, who on one occasion had two jobs on his desk: diplomatic notes from two antagonistic powers.) Such a situation, in other times and places might have led to the interpreter being killed by one or the other of his clients, unhappy at a negative reply to a diplomatic note.

Canada is mentioned but briefly, in the context of early French contact with aboriginal peoples. Mathieu da Costa (or d'Acosta) who knew French and Mikmaq in addition to his native Portuguese was, apart from the first Black on what was to become Canada, went into the service of Sieur des Monts and contributed to the good relations 
between the French explorers and the Mikmaq. But others had more complicated lives: Étienne Brulé, a young Frenchman who learned Huron, later went over to the enemy and worked for the English, and, according to some stories ended up being tortured and eaten by the Huron for his politics. Also, the ideology of the interpreter may get in the way of a "clean" interpretation, as was the case of early interpreters in New France who, as Huguenots, refused to interpret for the Catholic orders, dominant in the new colony. The problem was solved by their being replaced by Jesuit-trained interpreters.

Roland is especially interesting on the topic of the history of the training of interpreters. In earliest times (except in China and Japan), their bilingual ability was a feature of their family or early life circumstances; they were not products of interpreter training programmes. But in Ancient Egypt, a special Egyptian-Greek interpreters' caste was formed; in Ancient Greece, young Persians were instructed in Greek, and in Ancient Rome, bilingual instruction in Latin and Greek was the mark of a cultured citizen. Byzantium had an Office for Barbarians, who learned the customs and languages of the subject peoples in that vast empire. In fourteenth century Toledo, a quadrilingual translation centre flourished in Arabic, Hebrew, Spanish and Latin. The Ottoman Empire established a caste-like institution of dragomen of Turks and foreign nationals who conducted interpretation between the Turks and Europeans. In China, civil service examinations of translators and interpreters were set up in ten foreign languages; their positions eventually became hereditary, even though such positions were considered low-status, since the interpreters were required to have contact with despised "barbarians".

The quality and quantity of the analysis falls off sharply after the Second World War. There is an interesting anecdote of the linguistic confusion which reigned at the onset of the United Nations, but little mention of the European Union or the contemporary situation of interpreters in diplomacy or interpreter training.

Nevertheless, Roland's book is a highly readable survey of the development of the profession of diplomatic interpreter, while standing on substantial scholarly foundations ( 25 pages of bibliography, principally of works cited in English and French). As a teacher in a Canadian university faculty (Glendon College) founded by a Canadian diplomat (Escott Reid) to produce bilingual public servants with a broad liberal arts and internationalist outlook, I feel that my colleagues 
and I carry on a proud 4500-year-old tradition of linguisticallyenlightened intercultural communication. This book invites all its readers to belong to the same noble tradition.

\section{Ian Martin \\ English Department \\ Glendon College \\ York University}

\section{Kristal, Efraín. Invisible Work. Borges and Translation, Nashville, Vanderbilt University Press, xxii, 2002, 213 p.}

Outre le fait d'être des monuments de la littérature latino-américaine contemporains, quel autre trait partagent Gabriel García Márquez, Carlos Fuentes et Mario Vargas Llosa?

Celui de l'appropriation! García Márquez n'a-t-il pas transformé le comté de Yoknapatawpha de Faulkner en Macondo et fait de la ligne du temps de Buddenbrooks de Thomas Mann la colonne vertébrale généalogique de la famille Buendía? La mort d'Artemio Cruz de Fuentes n'est-elle pas une reprise du Citizen Cane d'Orson Welles? Vargas Llosa n'a-t-il pas réécrit Joseph Conrad et Victor Hugo entre autres?

C'est en tout cas ce qu'affirme Efraín Kristal pour expliquer l'héritage légué par Jorge Luis Borges (1899-1986) à la littérature latino-américaine et mondiale.

Professeur à l'UCLA et détenteur d'un doctorat de Stanford, Efraín Kristal est spécialiste de la littérature hispano-américaine des $\mathrm{XIX}^{\mathrm{e}}$ et $\mathrm{XX}^{\mathrm{e}}$ siècles et de littérature comparée. Il a notamment publié plusieurs ouvrages sur Mario Vargas Llosa dont Temptation of the Word (1998) et divers articles sur J.L. Borges.

Jorge Luis Borges, donc, le plus universel des écrivains latinoaméricains était copieur, adaptateur, faussaire, génie, éternel insatisfait, rêveur, misogyne, hétéro, narcissique ; telle apparaissait la personnalité du maître de la réécriture et de la retraduction.

« Je n'écris pas, je réécris. C'est ma mémoire qui produit mes phrases. J'ai tellement lu et tant entendu. Je l'avoue : je me répète. Je 